\title{
Cyclopia syndrome
}

\section{Deepak Sharma, Jaivinder Yadav, Eva Garg}

Department of Paediatrics, Pt.B.D.S PGIMS, Rohtak, Haryana, India

\section{Correspondence to}

Dr Deepak Sharma, dr.deepak. rohtak@gmail.com

Accepted 25 May 2014
CrossMark

To cite: Sharma D, Yadav J, Garg E. BMJ Case Rep

Published online: [please include Day Month Year] doi:10.1136/bcr-2014203535

\section{DESCRIPTION}

\section{Case}

A male baby with birth weight of $3.2 \mathrm{~kg}$ was born to primi mother at term gestation. The baby had Apgar score of $7 / 8 / 8$ and at birth was diagnosed to have microcephaly, cleft palate, single eye with absence of nose. On echo the baby had ventricular septal defect as congenital heart defect. The baby expired at the age of $10 \mathrm{~h}$ (figure 1). His parents did not give consent for a post mortem.

\section{Discussion}

Cyclopia (also cyclocephaly or synophthalmia) is a rare form of holoprosencephaly and is a congenital disorder (birth defect) characterised by the failure of the embryonic prosencephalon to properly divide the orbits of the eye into two cavities. It is the severest facial expression of the holoprosencephaly syndrome. ${ }^{1}$ Its incidence is 1 in 100000 in newborns. ${ }^{2}$ Typically, the nose is either missing or replaced with a non-functioning nose in the form of a proboscis. Such a proboscis generally appears above the central eye, or on the back, and is characteristic of a form of cyclopia called rhinencephaly or rhinocephaly. ${ }^{3}$ Most such embryos are either naturally aborted or are stillborn on delivery. Some

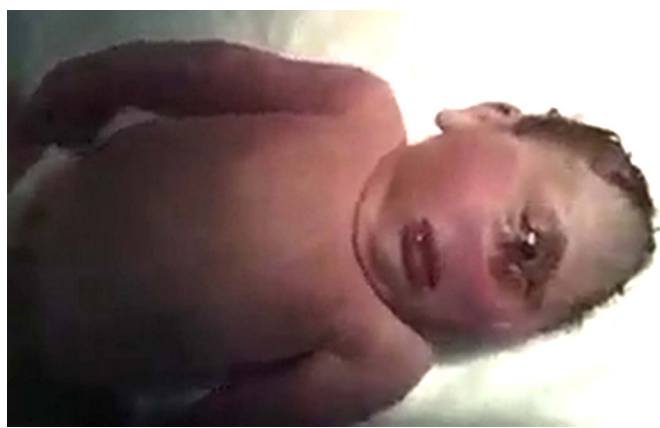

Figure 1 Picture of the newborn with cyclopia syndrome. Note single eye in centre of face. cases of cyclopia have been associated with a rare chromosomal condition called 'Patau Syndrome' (trisomy 13). ${ }^{4}$ SHH (Sonic Hedgehog Gene Regulator) is involved in the separation of the single eye field into two bilateral fields. Although not proven, it is thought that $\mathrm{SHH}$ emitted from the prechordal plate suppresses Pax6 which causes the eye field to divide into two. If the $\mathrm{SHH}$ gene is mutated, the result is cyclopia, a single eye in the centre of the face. ${ }^{5}$

\section{Learning points}

Cyclopia syndrome is a very rare syndrome of severe facial dysmorphism.

- Always look for associated malformations and chromosomal disorders which result in this abnormality.

Contributors DS and EG wrote the primary manuscript. JY made the final correction.

\section{Competing interests None.}

Patient consent Obtained.

Provenance and peer review Not commissioned; externally peer reviewed.

\section{REFERENCES}

1 Orioli IM, Amar E, Bakker MK, et al. Cyclopia: an epidemiologic study in a large dataset from the International Clearinghouse of Birth Defects Surveillance and Research. Am J Med Genet C Semin Med Genet 2011;157C:344-57.

2 Källén B, Castilla EE, Lancaster PA, et al. The cyclops and the mermaid: an epidemiological study of two types of rare malformation. J Med Genet 1992:29:30-5.

3 DeMyer W, Zeman W. Alobar holoprosencephaly (arhinencephaly) with median cleft lip and palate: clinical, electroencephalographic and nosologic considerations. Confin Neurol 1963;23:1-36.

4 Roessler E, Muenke M. Holoprosencephaly: a paradigm for the complex genetics of brain development. J Inherit Metab Dis 1998:21:481-97.

5 Roessler $\mathrm{E}$, Muenke M. The molecular genetics of holoprosencephaly. Am J Med Genet C 2010;154C:52-61.

Copyright 2014 BMJ Publishing Group. All rights reserved. For permission to reuse any of this content visit http://group.bmj.com/group/rights-licensing/permissions.

BMJ Case Report Fellows may re-use this article for personal use and teaching without any further permission.

Become a Fellow of BMJ Case Reports today and you can:

- Submit as many cases as you like

- Enjoy fast sympathetic peer review and rapid publication of accepted articles

- Access all the published articles

- Re-use any of the published material for personal use and teaching without further permission

For information on Institutional Fellowships contact consortiasales@bmjgroup.com

Visit casereports.bmj.com for more articles like this and to become a Fellow 